\title{
Evaluation of charged molecules content of plant poly- saccharides by aqueous size exclusion chromatography
}

\author{
Boymirzaev A.S. ${ }^{1,2}$, Pranovich A. ${ }^{2}$, Willför S. ${ }^{2}$ \\ ${ }^{I}$ Namangan Institute of Engineering and Technology, Department of Physics, Uzbekistan \\ ${ }_{2}^{2}$ Åbo Akademi University, Process Chemistry Centre, Turku/Åbo, Finland
}

Received 30.03.2017

\begin{abstract}
Aqueous size-exclusion chromatography (SEC) equipped with refractive index (RI) and multiangle laser light scattering (MALLS) detectors were applied to evaluation of charged molecules content in a series of polysaccharide derivatives with different average molar mass (MM) values. It was shown that a minor amount of residual charged groups in the polysaccharide chains caused a polyelectrolyte expansion effect and neutral fractions of birch xylans, larch arabinogalactans (AG) and galactoglucomannans (GGM) were separated from neutral molecules in various concentrations of the injected samples.
\end{abstract}

Keywords: size exclusion chromatography, molar mass, heteropolysaccharides, polyelectrolyte expansion, concentration effects.

\section{Оценка содержания заряженных молекул в расти- тельных полисахаридах методом водной эксклюзи- онной хроматографии}

\author{
Боймирзаев А.С. ${ }^{1,2}$, Пранович А. ., Виллфор С. ${ }^{2}$ \\ ${ }^{1}$ Наманганский инженерно-технологический институт, кафедра «Физика», Наманган, Узбекистан \\ ${ }^{2}$ Университет Академии Або, Центр химических процессов, Турку/Або, Финляндия
}

Для оценки содержания заряженных молекул в серии производных с различными средними молекулярными массами была использована водная эксклюзионная хроматография снабженная рефрактометрическим детектором и детектором многоуглового рассеяния лазерного света. Показано, что при различных концентрациях вводимой пробы разные количества заряженных групп в полисахаридной цепи были разделены от нейтральных фракций ксиланов березы, арабиногалактанов лиственницы и галактоглюкоманнанов за счет эффекта полиэлектролитного набухания.

Ключевые слова: Эксклюзионная хроматография, молекулярная масса, гетерополисахариды, полиэлектролитное набухание, концентрационные эффекты

\section{Introduction}

Size Exclusion Chromatography often referred to as Gel Permeation Chromatography (GPC), is one of the most powerful methods for investigation and determination of molar-mass distribution (MMD) of polymers $[1,2]$. SEC is a separation technique in which molecules are separated on the basis of their hydrodynamic volume or size. This paper aims to evaluate of charged anionic groups content of molecules in birch xylans, AG and GGM dissolved in water, as well as the influence of injected polymer concentrations to polyelectrolyte expansion effects in aqueous SEC. 
SEC of polysaccharides and polyelectrolytes presents special difficulties because the molecular size and shape are subject to large variations with ionic strength, injected polymer concentration and content of the mobile phase [3].

Biopolymers, defined broadly as biosynthesized materials, play a central role in medicine and pharmacy with applications in tissue engineering, regenerative medicine, and drug-carrier systems. Such materials are advantageous in biomedical and pharmaceutical applications because of their inherent properties of biocompatibility and biodegradation. From the forest industry point of view, potential polysaccharides for such applications could be wood-derived AG, GGMs, xylans and pectins. It is well known that for separation by SEC to be based purely upon differing degrees of exclusion of the macromolecules from the pores of the stationary phase, there must be no interaction (electrostatic or hydrophobic) between these molecules and the matrix of the network filled with the stationary phase. With carbohydrates, having a high proportion of hydroxyl and other polar groups, adsorption or electrostatic interaction to a polar matrix is likely to influence retention. In the case of polysaccharides, also intermolecular electrostatic interactions have to be considered. In such cases, not only the appropriate choice of the mobile phase, but also the choice of stationary phase is particularly important. Over the past fifty years, a huge amount of theoretical and empirical knowledge has been collected concerning the relationship between polymer structure, size and shape, interactions, and hydrodynamics for a large number of synthetic and biological polymers [1-11]. However, it is still needed to evaluate content of charged species in polysaccharide separation process and investigate the influence of the injected sample concentration.

The aim of this study was to investigate the concentration dependence of the retention volumes in SEC and determine the charged anionic groups in molecules of AG from larch, spruce GGM and birch xylans applying water as eluent.

\section{Experimental}

Larch AG (Ara:Gal)=15:85 was obtained from Megazyme International Ireland Ltd., Ireland . (+) AG from larch wood; 4-O-Methyl-D-Glucurono-D-xylan; Spruce GGM was isolated from spruce sapwood sawdust with pressurized hot water at $170^{\circ} \mathrm{C}$ during 20 min, precipitated to ethanol:water $(85: 15 \% \mathrm{v} / \mathrm{v})$, filtrated and dried in vacuum-dessicator at $40^{\circ} \mathrm{C}$ according to Tao Song et al. [12]. Birch xylan was provided by Metla, Finland. The xylan was extracted from birch sawdust with pressurized hot water at $160^{\circ} \mathrm{C}$ for $1 \mathrm{~h}$ and precipitated to ethanol:water $(85: 15 \% \mathrm{v} / \mathrm{v})$, filtrated and dried in vacuum-dessicator at $40^{\circ} \mathrm{C}$ according to P. Kilpeläinen et al. [14]. Acid methanolysis and gas_chromatographic (GC) analysis of heteropolysaccharides applied in the study was performed using $2 \mathrm{M} \mathrm{HCl}$ in anhydrous methanol at $105^{\circ} \mathrm{C}$ during 3 hours according to Sundberg et al. [15].

The SEC system was composed of an Agilent 1100/1260 Series chromatograph with a quaternary pump with degasser (G1311B), an autosampler (G1329A), two Ultrahydrogel Linear columns (300 x $8 \mathrm{~mm}$ ) from Waters (USA) connected in series, a differential refractometer (RID10A, Shimadzu) and MALLS (Mini DAWN TriStar, Wyatt Technology Corporation) with a semiconductor laser diode at $690 \mathrm{~nm}$. The SEC conditions were as follows: degassed water was used as eluent, the sample concentration was $1-4 \mathrm{mg} / \mathrm{mL}$, and samples were dissolved for $24 \mathrm{~h}$ under shaking, injection volume varied from 50 to 200 $\mu \mathrm{L}$, flow rate was maintained at $0.5 \mathrm{~mL} / \mathrm{min}$, and the column and detector temperature were kept at $40^{\circ} \mathrm{C}$. Before injection, the sample solutions were filtered through a $0.45 \mu \mathrm{m}$ nylon membrane (Sartorius, Germany). An inline filter (Wyatt Technology Corporation) was installed between the pump and the autosampler to remove any particles from the mobile phase. 


\section{Results and discussion}

Table 1 summarizes the main structural features of the heteropolysaccharides, subjected for SEC analysis.

Table 1. Composition of heteropolysaccharides determined by acid methanolysis, GC and SEC

\begin{tabular}{|c|c|c|c|c|}
\hline № & Polysaccharide & $\begin{array}{c}\text { Main sugar units ratio } \\
(\mathrm{mol} / \mathrm{mol})\end{array}$ & VR, min & Elution profile \\
\hline 1 & AG & Gal:Ara $(6.3: 1)$ & $24 ; 26$ & bimodal \\
\hline 2 & GGM & $\begin{array}{c}\text { Man:Glc:Gal } \\
(5.8: 1.4: 1)\end{array}$ & 27 & bimodal \\
\hline 3 & Xylan & Xyl:MeGclA $(17.2: 1)$ & 17 & bimodal \\
\hline
\end{tabular}

As follows from Table 1, AG is a principal, highly branched heteropolysaccharide in larch heartwood. The backbone of AG is build up by 1-3 linked galactopyranose units. Its side chains, which consist of mostly galactopyranose and some arabinose residues, attached to position 6 of almost every galactose units in backbone. Both applied to study larch arabinogalactans have close main sugar Gal:Ara units molar ratio, i.e. 6.3:1 preparation from Megazyme Ltd. (Table1). GGM is another important heteropolysaccharide dominating in coniferous wood, particularly in spruce stem. It is a structural cell wall component, located mostly in the S2 layer. Compared to AG, GGM is only slightly branched polymer with main backbone build up by 1-4 linked mannopyranose and some glucopyranose units. Xylose-based plant cell wall heteropolysaccharide, i.e. O-acetyl-4-Omethylglucurono-b-D-xylan or simply xylan, is principal component in hardwood species and grasses. Some portion of xylan, however, can also be found in softwood. Typically, xylan's backbone consists of 1-4 linked xylopyranose units. It is known as "acidic polysaccharide" since xylose unit in xylan chain also carries 1-2 linked 4-O-methyl-a-Dglucuronic acid. The Xyl:MeGlcA units ratio in 4-O-methylglucurono-xylan from Sigma was determined 14.2:1 and that isolated from birch wood by PHWE - 17.2:1 (Table 1).

Fig.1-3 represent elution profiles of AG, GGM and xylans registered by RI detector in applying water as eluent at various of injected polymer concentrations.

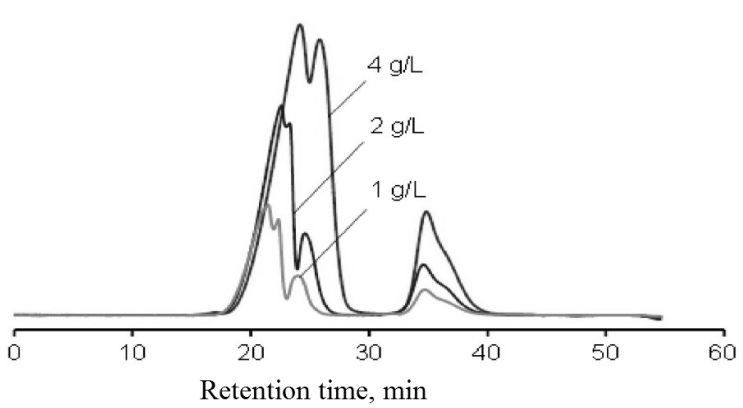

Fig. 1. Elution profiles of larch arabinogalactan (Megazyme)

$\mathrm{M}_{\mathrm{w}}=40 \mathrm{kDa}$ at 3 injected concentrations. Eluent: $\mathrm{H}_{2} \mathrm{O}$. Detector: $\mathrm{RI}$

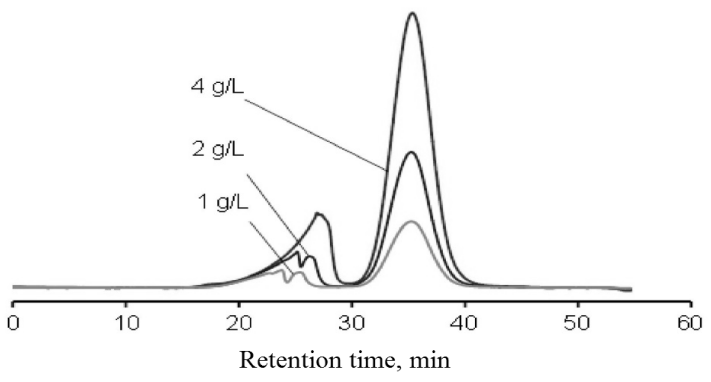

Fig. 2. Elution profiles of galactoglucomannan isolated from spruce wood with hot-water extraction $\mathrm{M}_{\mathrm{w}}=20 \mathrm{kDa}$ at 3 injected concentrations. Eluent: $\mathrm{H}_{2} \mathrm{O}$.

In SEC with pure water as eluent, some electrostatic effects, such as polyelectrolyte expansion, distort the separation mechanism of AGs, xylans, and GGMs. In separation of larch AG, multimodal chromatograms were found: the first peaks were appearing near the void volume of the column, thus indicating the presence of charged anionic groups in the 
molecules (Fig.1). Such effect was also earlier detected in separation of Siberian larch AG $[16,17]$ at low ionic strength of eluent and this phenomenon was described due to intramolecular electrostatic effects rather than to ion exclusion. A further problem was shown to be the presence of a small proportion of galacturonic acid units in AG from the larch species, which causes non size-exclusion behavior of the polysaccharide when eluents of low ion strength are used.

Fig. 1 presents the combined elution profiles of larch AG at three injected sample concentrations 1,2 , and $4 \mathrm{~g} / \mathrm{L}$. The chromatograms consist of at least three distinct fractions and two of them are early-eluted peaks belonging to ionic species of AG in water. The decrease in retention volume of early eluted multiple peaks with reduction of injected sample concentration indicated the presence of electrostatic effects in the system. The decrease of the concentration in the injected sample leads to an increase of the size of the macromolecules and to their early elution, correspondingly the retention volume will be decreased. Intramolecular electrostatic interactions that can lead to polyelectrolyte expansion effects in SEC of charged polymers are seen in the concentration effects as a decrease in the retention volume $\left(\mathrm{V}_{\mathrm{R}}\right)$ with reduction of injected sample concentration $C$.

The same effect as described above appeared in the SEC analysis of xylans and GGM in pure water. As shown in the chromatogram of GGM (Fig. 2) in pure water, multimodal peaks were detected: the first asymmetric peaks are separated from symmetric neutral species and the retention volume of the main neutral peak did not change with the decrease in the injected sample concentration. The retention volumes of the asymmetrical early eluted peaks decreased with the reduction of concentration of the solutes and the elution profiles of GGM in the chromatograms indicate that part of the polysaccharide molecules are charged and eluted earlier than the neutral fraction.

The elution profiles of the birch xylan (Fig.3) samples indicate that most of the polymeric molecules were charged in pure water. Asymmetric and multimodal distribution profiles received at different sample concentrations also indicate the electrostatic effects nature of charged species.

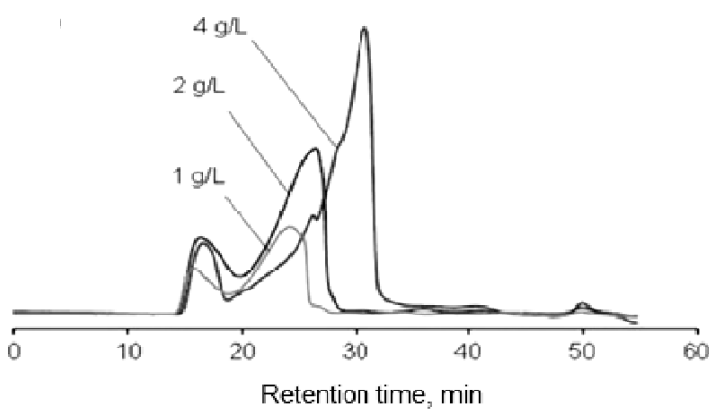

Fig. 3. Elution profiles of xylan isolated from birch wood $\mathrm{M}_{\mathrm{w}}=40 \mathrm{kDa}$. Eluent: $\mathrm{H}_{2} \mathrm{O}$.

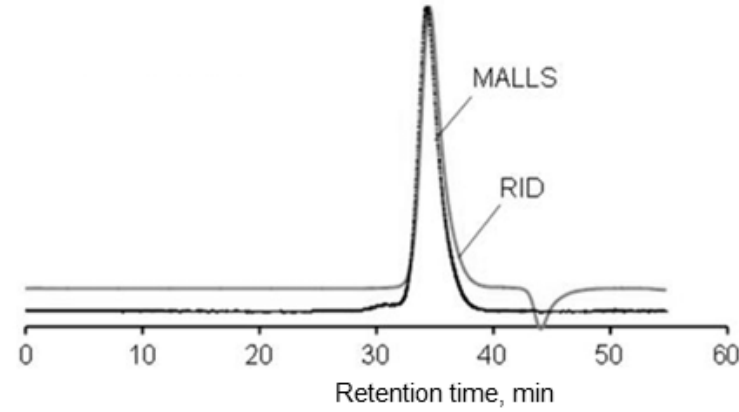

Fig. 4. Elution profiles of larch arabinogalactan (Sigma) $\mathrm{M}_{\mathrm{w}}=40 \mathrm{kDa}$ after elimination of electrostatic effects. Eluent: aqueous 0.1M $\mathrm{NaNO}_{3}$

Willför et al. [19] reported that the structure of the AG from spruce and pine were found slightly different from the structure of larch AG. The amount of single unit sidechains, consisting of arabinose and glucuronic acid units, was higher in the spruce and pine AG than in the larch AG. The amount of glucuronic acid was higher in the spruce AG than in the pine AG. Although the general structural features of larch AG have been extensively investigated in the past [20], many uncertainties regarding the molar mass and fine structure concerning the heterogeneity, and branching, remain unresolved.

Fig.4 shows the elution profiles of Larch AG after suppression of electrostatic expansion using of the eluent $0.1 \mathrm{M} \mathrm{NaNO}_{3}$ in water registered by MALLS and RI detectors. 
As indicated in [3], increase of ionic strength of eluent in SEC will lead to screen of Coulombic forces of fixed electrostatic charges in polyelectrolyte chains. In result, intramolecular electrostatic repulsion decreases and conformation of polyions became as Gaussian coil. As shown in Fig.4, both detectors are registered symmetrical Gaussian peaks that can be attributed as suppression of electrostatic effects of AG in salt solution

\section{Conclusion}

Elution properties of polysaccharides have been studied by SEC/MALLS/RI. In pure water as eluent acidic species contained in these polysaccharides will lead to polyelectrolyte effects, particularly electrostatic expansion and in result to early elution of charged molecules. Neutral fractions of GGM and birch xylans are separated from charged fractions according to size-exclusion mechanism in $\mathrm{H}_{2} \mathrm{O}$. Polyelectrolyte effects in SEC of AG, GGM and xylans are suppressed by using $0.1 \mathrm{M} \mathrm{NaNO}_{3}$ in $\mathrm{H}_{2} \mathrm{O}$. Concentration dependence of retention volume of larch AG, spruce GGM and birch xylans are indicated the polyelectrolyte nature of these polysaccharides in water and determination of amount of charged anionic groups in polysaccharide chains will be subject of our further investigations.

Financial support from the Johan Gadolin Scholarship Program at Åbo Akademi University is highly appreciated. We wish to thank Dr. A.Tokarev from Laboratory of Industrial Chemistry and Reaction Engineering, Abo Akademy University for presenting of arabinogalactan and Petri Kilpeläinen (Metla, Finland) for birch xylan for investigation.

We also thank Jarl Hemming for technical assistance with SEC-MALLS instrument. This work was part of the activities at the Abo Akademi Process Chemistry Centre

\section{References}

1. Barth, H.G., Boyes, B.E., Jackson, Ch. Analytical Chemistry.1998, Vol 70, pp. 251-278.

2. Churms, S.C. J.Chromatogr.Libr, 2002, Vol.66, pp.267-303.

3. Boymirzaev, A.Sorption and chromatographic processes, 2007, Vol.7, No 2, pp. 251258

4. Porsch, B. Andersson, M. Wittgren, B. Wahlund, K-G., J. Chromatogr. A.2002,Vol.946, pp.69-81

5.Boymirzaev,A.S.Shomurotov,Sh.Turaev,A.S. Chem.plant raw material.2013,No2,pp.51-55.

6. Provder,T. Chromatography of polymers: Characterization by SEC and FFF.1993,337 p.

7. Pasch, H. Trathnigg, B. HPLC of Polymers. Berlin. Springer-Verlag, 1999. 224 p.

8. Dubin P.L. Advances in Chromatography.1992, Vol.31, pp.119-151.

9. Jordan, R.S. J. Liq. Chromatogr. 1980,Vol.3, pp.439-463.

10. Froment, R, Revillon, A. J.Liq.Chromatogr 1987,Vol.10, pp. 1383-1397
11. Eigner, W-D, Abuja, P. Beck, R.H.F. Praznik, W. Carbohydr. Res.1988, Vol. 180, pp. 87-95

12. Song,T,Pranovich,A, Holmbom,B.Bioresource Technology. 2013, Vol.130, pp.198-203

13. Sundberg, A. Holmbom, B. Willför, S. Pranovich, A. Nordic Pulp \& Paper Research Journal. 2000, Vol.15, pp. 46-53

14. Kilpeläinen, P. Leppänen, K. Spetz, P. Kitunen, V. Ilvesniemi, H. Pranovich, A. Willför, S. Nordic Pulp and Paper Research Journal. 2012, Vol.27, pp. 680-688

15. Sundberg, A. Sundberg, K. Lillandt, C. Holmbom, B. Nord Pulp Pap.Res.19996, Vol.11, pp. 216-219

16. Eremeeva, T.E., Bykova, T.O. Carbohydrate polymers 1992, Vol.18, pp. 217219

17. Medvedeva, S.A, Aleksandrova, G.P, Tantsyrev, A.P. Forest Journal. 2002, No 6, pp.108-114

18. Ponder, G.R. Richards, G.N. J. Carbohydr.Chem. 1997, Vol.16, pp.181-193 
19. Willför, S. Sjöholm, R. Laine, C. Holm- 20. Stephen, A.M.The Polysaccharides, bom, B. Wood Science and Technology, 2002, New.York:Academic Press, 1983,Vol.2, pp.97Vol.36, pp.101-110 103.

Boymirzaev Azamat S. - Docent, Namangan Institute of Engineering and Technology, Department of Physics, Uzbekistan. +998 934011255 azamatsb@gmail.com

Willför Stefan - Professor, Åbo Akademi University, Process Chemistry Centre, Turku/Åbo, Finland, swillfor@abo.fi
Pranovich Andrey - Docent, Åbo Akademi University, Process Chemistry Centre, Turku/Åbo, Finland, +35822154987 apranovi@abo.fi 